\title{
Crotalus durissus venom: biological effects and relevant applications. A Review
}

Veneno da Crotalus durissus: Efeitos biológicos e aplicações relevantes. Uma Revisão

\author{
Lucelina da Silva Araújo ${ }^{1}$, Anna Sérgia Mendonça Miranda Conceição ${ }^{1}$, Duanny \\ Murinelly de Souza Cunha ${ }^{1}$, Glayciane Bezerra de Morais ${ }^{1}$, João Alison de Moraes \\ Silveira $^{2}$, Francisco Antônio Félix Xavier Júnior ${ }^{1}$, Karen Denise da Silva Macambira ${ }^{1}$, \\ Steffi Lima Araújo ${ }^{1}$, Nathalie Ommundsen Pessoa ${ }^{1 *}$, Janaina Serra Azul Monteiro \\ Evangelista $^{1^{*}}$
}

${ }^{1}$ Laboratory of Histology of Effects Caused by Snake Venoms and Plants, Veterinary College, State University of Ceara, Fortaleza, Ceara. E.Mail: lucelinaaraujo@ hotmail.com

${ }^{2}$ Laboratory of Pharmacology of Venoms, Toxins and Lectins, Medical School, Federal University of Ceara, Fortaleza, Ceara

*Authors for correspondence: nathalieop@gmail.com / janaina.azul@uece.br

\begin{abstract}
Snakes have an important biological role in the ecological chain, as well as in scientific researches performed with the venoms produced by them, since the enzyme-protein fractions these substances possess have been studied as pharmacological tools for the discovery of new therapies. Snakes of the genus Crotalus have gained significant relevance in the scientific field, since the venom produced by these reptiles has been the target of researchers in a few decades, due to the composition and the effects that these substances can produce. In Brazil, a single species represents the genus, which is Crotalus durissus. This review demonstrates that even with the advancement in scientific research on the composition, role and application of the venom produced by the subspecies of Crotalus durissus snake, it is necessary to further study their fractions and their action potential, which also demonstrates the how rich are these active components in different fields of biomedicine.
\end{abstract}

Keywords: snake toxins, crotoxin, phospholipase A2, gyroxin.

Resumo: As serpentes possuem um papel biológico importante na cadeia ecológica, como nas pesquisas realizadas com os venenos por elas produzidos, uma vez que suas frações enzimáticasproteicas vêm sendo estudadas como potenciais ferramentas farmacológicas para descoberta de novas terapias. As serpentes do gênero Crotalus tem ganhado relevante espaço no campo científico, visto que em algumas décadas seu veneno vem sendo alvo de pesquisadores devido sua constituição e o efeito que essas substâncias podem causar. No Brasil, este gênero é representado por apenas uma espécie, a Crotalus durissus. Esta revisão de literatura demonstra que, mesmo com o avanço em pesquisas científicas sobre a composição, atuação e aplicação do veneno da serpente Crotalus durissus e suas subespécies, torna-se necessário estudos mais aprofundados principalmente no que diz respeito 
as suas frações e seus potenciais de ação, o que também demonstra a riqueza em atividade desses componentes em diversos ramos da biomedicina.

Palavras-chave: toxinas ofídicas, crotoxina, fosfolipase A2, giroxina.

*Authors for correspondence: * nathalieop@gmail.com / * janaina.azul@uece.br Recebido em 10.01.2016. Aceito em 20.03.2016 http://dx.doi.org/10.5935/1981-2965.20160002

\section{Introduction}

The crotalic venom is presented as an enzyme-toxic complex of various substances. Among the enzymes are: proteases, phosphodiesterase, L-amino acid oxidase, 5'-nucleotidase and fractionation of this venom reveals toxins such as crotoxin, crotamine, gyroxin, convulxin and serine proteinases (RANGELSANTOS et al., 2004; FONSECA et al., 2006). The different components of the venom are reflected in the variations of their biological properties, toxicity and activity characteristics. The toxicity of the venoms is presented at varied times and in different clinical manifestations, which are due not only to their specific properties, but also to their toxicokinetics, composition and potency of the substance.

Snakes of the genus Crotalus have gained significant relevance in the scientific studies, and the venom produced by these reptiles has been the target of researchers in a few decades, due to their composition and the effects that these substances can cause. Most venoms affects almost all types of cells and tissues of the human body where their pharmacological properties are determined by the specific amount of biologically active constituents. About $90-95 \%$ of the dry weight of snake venoms have protein properties, and these proteins are responsible for almost all of the biological effects found. Lucien Bonaparte established the proteinaceous nature of these venoms in 1843 (BON, 2006).

Therefore, it is important to study the effects of the venom of Crotalus durissus species, snake largely found in Brazilian territory, performing a review about the main components, aiming to better understand their biological effects and mechanisms of action.

\section{General characteristics and territorial distribution \\ The Viperidae family presents} great expertise in skull morphology, with extreme mobility of the jaw and other bones of the head. The venom of these snakes is produced by two special glands 
located in the head, behind and below the eyes, which are nothing more than modified salivary glands, where saliva is the actual toxin.

They have stocks for multiple bites, and, once the venom or secretion is completely extracted, the glands will again be filled completely only after two weeks (SANTOS, 1995).

Snakes of the genus Crotalus are represented in Brazil by a single species, Crotalus durissus, which is further divided into the following subspecies: Crotalus durissus terrificus, found in the southeast and south regions; Crotalus durissus collilineatus, distributed in dry areas of the midwest region, in Minas Gerais State and in the north of São Paulo State; Crotalus durissus cascavella, found in the caatinga bioma of the northeast region; Crotalus durissus ruruima observed in the north region; and Crotalus durissus marajoensis observed in Marajó Island (PINHO \& PEREIRA, 2001). Some authors recognize a sixth subspecies in Brazil, the Crotalus durissus trigonicus, found in some regions of Roraima State (CAMILLO, 1998).

\section{Constituents of the venom of crotalus durissus species}

\subsection{Crotoxin and subunits}

The crotoxin, which is the main polypeptide present in the venom, was isolated initially by SLOTTA \& FRAENKEL-CONRAT in 1938. Silva
(1982) when isolating the crotoxin again from the subspecies Crotalus durissus terrificus, pointed out that this component accounted for $68 \%$ of the total weight of the venom.

According to Hendon \& FraenkelConrat (1971), crotoxin $(24 \mathrm{kDa})$ is a $\beta$ neurotoxin that has two subunits, an acid, the crotapotin (crotoxin A) and a base, phospholipase A2 (crotoxin B).

Crotoxin has pre and postsynaptic blocking effects. Pre-synaptically, it interferes with the release of acetylcholine by blocking neuromuscular transmission and preventing the contraction of skeletal striated muscle; while postsynaptically, it acts by decreasing the action of acetylcholine and prevents membrane depolarization. It can cause paralysis of the respiratory muscles, culminating in the death of the envenomed individual. It also increases the permeability of sodium ions (BON et al.,

1979;

GOPALAKRISHNAKONE et al., 1984; RANGEL-SANTOS et al., 2004). The venom of Crotalus terrificus durrissus and crotoxin $\mathrm{B}$ induces protein expression of cyclooxygenase-2 by endothelial cells (MATSUBARA, 2009).

Interspecific and intraspecific variations have been described for the crotoxin complex. Intraspecific variations differ in the presence of different isoforms of subunits $\mathrm{A}$ and $\mathrm{B}$, which possess 
different potency and varied biological activity (PEREAÑEZ et al., 2009). According to Rangel-Santos \& colleagues (2004) even with an electrophoretic profile similar in subspecies Crotalus durissus cascavella, Crotalus durissus collilineatus and Crotalus durissus terrificus, there are differences in their activities, which may be related to the existence of different isoforms of crotoxin. The crotapotin acidity is justified by their amino acid composition: 12 aspartate/asparagine residues and 14 glutamate/glutamine versus 2 lysine residues and 2 arginine. The crotalic phospholipase A2 contains 11 aspartate/asparagine and 10 glutamate/glutamine residues versus 11 lysine and 12 arginine residues, characterizing the base property of the substance. The crotapotin and the phospholipase A2 are rich in cystine containing 7 and 8 disulphide bridges, respectively. The two subunits form the crotoxin, molar complex with a 1:1 ratio (BREITHAUPT et al., 1974).

Crotapotin has no toxicity nor enzymatic activity of crotoxin, but enhances the toxicity. This potentiation can be explained by the fact that, when combined with component B (PLA2), the component A (crotapotin) prevents the binding of PLA 2 to low specificity and affinity sites, directing the PLA2 to sites of membrane receptors (postsynaptic) with high specificity and high affinity, which enhances the toxicity of crotoxin. These receptors were designated as type $\mathrm{N}$ (neuronal) and $\mathrm{M}$ (muscle). The receivers of the type $\mathrm{N}$ were the first to be identified and are present in large quantities in rat brain membranes. These receptors bind with high affinity to neurotoxic PLA2. As for the type $M$ receptors have been identified in skeletal striated muscle of rabbits (MATSUBARA, 2009).

Crotapotin has demonstrated the ability to potentialize the inflammatory edema (induced by carrageenan), possesses antimicrobial effect on Gram negative bacteria and elevates the renal perfusion pressure and renal vascular resistance in perfused kidneys (without, however, altering the urinary flux or glomerular filtration, in opposed to the crotoxin) (MARTINS et al., 2003; OLIVEIRA, et al., 2003).

Unlike the venom of Crotalus durissus terrificus, which contains three or four PLA2 isoforms; the venom of Crotalus durissus cascavella contains at least four crotoxin isoforms formed by various combinations of crotapotins with one isoform of phospholipase A2 (PLA2) (BEGHINI et al., 2000). These data can serve as evidence to suggest differences in the action intensity of the venom from different subspecies.

The PLA2 induces plasma extravasation and is able to increase microvascular permeability of the skin at 
the dorsal region of rats. The mechanisms of PLA2 induced edema formation involves the activation of sensory $\mathrm{C}$ fibers, which release neuropeptides such as substance $\mathrm{P}$, which mediate neurogenic local inflammatory effects (vasoactive responses) in innervated tissues and local mast cells (by substance P), which release histamine and serotonin (CÂMARA et al., 2003). FONSECA \& colleagues (2006) reported that crotoxin presents two different enzymatic activities (PLA2 and serine protease) and two different types of biological actions (neurotoxic and coagulant).

\subsection{Crotamine}

The crotamine is a basic polypeptide, belonging to the family of basic polypeptidic myotoxins, which have intracellular penetration capacity through mechanisms independent of energy expenditure by interaction with proteoglycans of the extracellular matrix (MATSUBARA, 2009). The myotoxic effect is caused by this toxin, which presents synergistic activity with crotoxin. It acts mainly causing muscle contractions dependent of depolarization of the skeletal striated muscle cells by increasing the sodium ion permeability of the membrane. This effect probably occurs on these ion channels by inducing calcium influx (LOMONTE et al., 2003). Additionally, it is known that crotamine actively interacts with the lipid membranes of cells forming vacuoles and showing a myonecrotic activity.

\subsection{Convulxin}

The convulxin is a toxin with high molecular weight, belonging to the family of C-type lectins isolated from Crotalus durissus terrificus venom, Crotalus durissus cascavella and Crotalus durissus collilineatus consists of a potent platelet activator. According to Lima \& colleagues (2005) besides inducing platelet aggregation by binding to GPVI platelet receptor, it also causes seizures, respiratory and circulatory alterations. It is composed of two polypeptide chains $(\operatorname{Cvx} \alpha$ e $\operatorname{Cvx} \beta)$ covalently associated in a trimeric structure $(\alpha \beta) 3$. The platelet induction by this toxin consists of a $\mathrm{Ca}^{2+}$ dependent reaction, initiated by the binding of convulxin to the GPVI platelet receptors (POLGÁR et al., 1997; JANDROT-PERRUS et al., 1997; KANAJI et al., 2003).

Leduc \& Bon (1998) cloned and sequenced both strands of convulxin of Crotalus durissus terrificus. In this study, a high similarity between $\alpha$ and $\beta$ chains, with an average of $74 \%$ identity percentage was observed. The sequencing of the subunits resulted in chains comprising 158 and 148 amino acid residues in $\operatorname{Cvx} \alpha$ and $\operatorname{Cvx} \beta$, respectively, and a signal peptide of 23 amino acid residues identical for both the subunits. Toyama \& colleagues (2001) 
isolated and characterized a convulxin-like protein from the Crotalus durissus collilineatus venom with a high similarity to the convulxin of Crotalus durissus terrificus.

\subsection{Gyroxin}

The gyroxin converts fibrinogen into fibrin, thereby increasing clotting time (SANO-MARTINS et al., 2001). This toxin belongs to the thrombin family and was isolated from the venom of Crotalus durissus terrificus (RAW et al., 1986). In addition to this performance, excellent neurotoxic activity have also been described (BARROS et al., 2011).

Fonseca \& colleagues (2006) described gyroxin presenting two main fractions: one with thrombin-like activity and other L-amino acid oxidase (LAAO). LAAO is the only oxidase dependent FAD (flavin adenine dinucleotide) found in snake venom and toxicity possibly involves generation of hydrogen peroxide, the final product of L-amino acid oxidation. The LAAO also induces platelet aggregation, involving the activation of PLA2 (TOYAMA et al., 2006). In recent studies, Barros \& colleagues (2011) found that gyroxin demonstrated a high level of coagulation activity, with a minimum dose of $0.015-0.037 \mu \mathrm{g} / \mu \mathrm{L}$.

Prado-Franceschi (1990) suggests that this toxin produces a peculiar seizure syndrome in mice characterized by rapid movements rotating the body around the longitudinal axis. The study of this enzyme could serve as a molecular model interesting for developing new drugs or therapeutic agents (MORAES et al., 2004; FERRARO et al., 2005), especially due to their resistance to physiological proteinase inhibitors (MATSUI et al., 2000; SERRANO \& MAROUN, 2005).

\subsection{Natriuretic peptide}

Another important component of the venom is the natriuretic peptide that was isolated from Crotalus durissus cascavella and was able to increase renal perfusion pressure and vascular resistance in isolated perfused rat kidneys. Increased urinary flow and glomerular filtration and reduced renal sodium tubular transport was also observed. In systemic blood pressure in vivo experiments, a decrease in mean arterial pressure, cardiac output and respiratory rate was observed. Therefore, this component of the venom showed renal and cardiovascular effects, with consequent hypotensive and diuretic effects (EVANGELISTA et al., 2008).

\section{Study of the toxic activity of the} crotalus genus venom and fractions

Over the decades, in several studies, researchers test venoms and their components. The venom of Crotalus durissus species have been tested under different perspectives, and among them, the observed were: cytotoxic, antibacterial, 
leishmanicide, analgesic, on hematological processes and activation of phagocytosis processes in viral infections; their influence on the nervous system; as well as activation of apoptotic pathways, or necrotic tumor cell lines phagocytosis. Some studies have also found effects of the venom on various cell types, such as macrophages, lymphocytes, platelets and tumor cells (SAMPAIO et al. 2005; YAN et al., 2006 e 2007).

Yan \& colleagues (2006) tested crotoxin, the main fraction of the crotalic venom and demonstrated the occurrence of autophagy and apoptosis in chronic myeloid leukemia cell line (K562). Tamieti \& colleagues (2007) reported that the venom of Crotalus durissus has the capacity to induce apoptosis in tumor hamster ovarian carcinoma cells (CHOK1). Also in 2007, the same authors repeated the study using another cell line, MCF-7, derived from human breast cancer. In this experiment, the stimulation of autophagy was yet observed, however to a lesser extent and being dose-dependent as well as apoptosis by condensation and nuclear fragmentation.

Another important researched component is the crotalic PLA2. Fonseca et al (2006) tested both crotoxin and the subunits crotapotin and PLA2 in human plasma rich in platelets and verified that the concentration of $20 \mu \mathrm{L}$ of crotoxin demonstrated potent action for platelet aggregation; while the major subunits were not able to provide the same potential when tested in separate.

The venom of Crotalus durissus terrificus has also been known by researchers who emphasize the analgesic activity, confirmed effect in pain experimental models (GIORGI et al., 1993; GUTIERREZ et al., 2008). More recently, Nogueira-Neto \& colleagues (2008) demonstrated that the crotoxin inhibit neuropathic pain induced by transection of the sciatic nerve in rats, when applied directly onto the stumps and also when it was administered to animals.

The mechanisms involved in analgesic action of the crotoxin may also vary according to the experimental model used to assess pain. Zhang \& colleagues (2006) and Zhu \& colleagues (2008), by using models of acute pain, demonstrated that muscarinic and opioid receptors are not involved in the analgesic effect of the crotoxin matched against Nogueira-Neto \& colleagues (2008) that reported activation of central muscarinic receptors was involved in analgesia induced by crotoxin in a model of neuropathic pain. Recently, an acid peptide identified in the venom of Crotalus durissus terrificus, named crotalphine, was determined as a major component in the analgesic activity, inducing a potent and long acting 
antinociceptive effect in neuropathic pain (KONNO et al., 2008; GUTIERREZ et al., 2008).

Concerning the action of venom on microorganisms, several studies have shown that the venom of Crotalus durissus species has bactericidal activity for a variety of species among, such as Burkholderia pseudomallei, Claribacter michiganensis michiganensis, Enterobacter aerogenes, Escherichia coli, Staphylococcus aureus, Pseudomonas aeruginosa, Xanthomonas axonopodis pv. passiflorae and can be affirmed that this activity is related to PLA2 (SOARES et al., 2001; OLIVEIRA et al. 2003; TOYAMA et al. 2003; SAMY et al., 2006 and 2007; DIZ FILHO et al., 2009).

Oliveira \& colleagues (2003) demonstrated that crotoxin isolated from the venom of Crotalus durissus cascavella was six times less active in Gram-negative bacteria than in Gram-positive bacteria. Also, that PLA2 present in the venom showed the same bactericidal effect on both types bacteria and that crotapotin inhibited bacterial growth rate, but the actions of the constituents varied in the way the effect was performed in the tested bacteria. The interest in some studies arose from researchers observed a very low frequency of bacterial infections that occurred in snakebite lesions, then suggesting this possible bactericidal activity. The biological activity of the venom of these snakes on parasites was also studied. Different crotalic venoms collected from subspecies Crotalus durissus terrificus, Crotalus durissus cascavella and Crotalus durissus collilineatus, when tested decreased the growth rate of Leishmania amazonensis (PASSERO et al., 2007). These results show that crotalic venoms may be protein sources with therapeutic potential against parasites causing leishmaniasis, the findings suggest that the growth of Leishmania amazonensis may have been affected by different routes, including the production of hydrogen peroxide and probably via recognition by cell surface receptors.

For the proteomic study, we can highlight studies involving the snakes Crotalus durissus collilineatus and Crotalus durissus cascavella when we define they had proteomes that comprehend gama proteins of $4-115 \mathrm{kDa}$, pertaining to 9 and 8 families of toxins, respectively (BOLDRINI-FRANÇA et al., 2011). Also, according with those studies, venoms of $C . d$. collilineatus e $C . d$. cascavella have 20-25 toxines pertaining to following families: desintegrin, PLA2, serine proteinases, cysteine-rich secretory protein (CRISP), vascular endothelialgrowth factor (VEGF), L-amino acid oxidase, c-type lectins-like and snake 
venom metalloproteinase (SMVP). Venom composition explains clinical manifestations developed in accidents caused for Crotalus durissus, such as, neurotoxicity, myalgia, coagulation disorders, often accompanied for myoglobinuria and acute renal failure.

\section{Conclusion}

In conclusion, we found several potential activities of the various components of the Crotalus durissus venom. Studies using bioactive natural substances are an excellent choice for the emergence of possible tools with physiopharmacological potential. Thus, snake venom and their components are widely tested. It is currently confirmed their potential antitumoral, bactericidal and leishmanicidal effects; activation of phagocytosis processes in viral infections; effect on hematological processes; biological action in the nervous system; and analgesic activity.

The venom of Crotalus durissus snake and subspecies of the Brazilian biodiversity, are of great value for the development of directed and advanced research lines focused on the application of the venom in several fields of biomedicine, but also for the scientific growth and the improvement of Brazilian research.

\section{References}

BARROS, L.C; SOARES, A.M.; COSTA, F.L.; RODRIGUES, V.M.; FULY, A.L.; GIGLIO, J.R.; GALLACCI, M.; THOMAZINI-SANTOS, I.A.; BARRAVIEIRA, S.R.C.S.; FERREIRA JUNIOR, R.S. Biochemical and biological evaluation of gyroxin isolated from Crotalus durissus terrificus venom. The Journal of Venomous Animals and Toxins including Tropical Diseases, v. 17, n. 1, p. 23-33, 2011.

BEGHINI, D.G.; TOYAMA, M.H.; HYSLOP, S.; SODEK, L.; NOVELLO, J.C.; MARANGONI, S. Enzymatic characterization of a novel phospholipase A2 from Crotalus durissus cascavella rattlesnake (Maracambóia) venom. Journal of Protein Chemistry, v. 19, n. 8, p. 679-684, 2000.

BOLDRINI-FRANÇA, J.; CORRÊA-NETTO, C.; SILVA, M.M.S.; RODRIGUES, R.S.; DE LA TORRE, P.; PÉREZ, A.; SOARES, A.M.; ZINGALI, R.B.; NOGUEIRA, R.A.; RODRIGUES, V.M.; SANZ, L.; CALVETE, J.J. Snake venomics and antivenomics of Crotalus durissus subspecies from Brazil: assessment of geographic variation and its implication on snakebite management. Journal of Proteomics, v. 73, n. 9, p. 17581776, 2011.

BON, C.; CHANGEUX, J.P.; JENG, T.W.; FRAENKEL-CONRAT, H. Postsynaptic effects of crotoxin and of its isolated subunits. European Journal of Biochemistry, v. 99, n. 3, p. 471-481, 1979.

BON, C. Snake venom and pharmacopoeia. In: BAUCHOT, R. (Ed.) Snakes: A Natural History. New York: Sterling Publishing Company, 2006. p. 194-209.

BREITHAUPT, H.; RÜBSAMEN, K.; HABERMANN, E. Biochemistry and pharmacology of the crotoxin complex. Biochemical analysis of crotapotin and the basic Crotalus phospholipase A. European Journal of Biochemistry / FEBS, v. 49, n. 2, p. 333-345, 1974. 
CÂMARA, P.; ESQUISATTO, L.; CAMARGO, E.; RIBELA, M.; TOYAMA, M.; MARANGONI, S.; DE NUCCI, G.; ANTUNES, E. Inflammatory edema induced by phospholipases A2 isolated from Crotalus durissus sp. in the rat dorsal skin: A role for mast cells and sensory c-fibers. Toxicon, v. 41, n. 1, p. 823-829, 2003.

CAMILLO, M. Contribuição ao estudo das giroxinas (enzimas semelhantes à trombina) dos venenos das serpentes brasileiras Lachesis muta muta e Crotalus durissus terrificus, 1998. 75f. Tese (Doutorado em Ciências) - Instituto de Pesquisas Energéticas e Nucleares, São Paulo, SP, 1998.

DIZ FILHO, E.B.S.; MARANGONI, S.; TOYAMA, D.O.; FAGUNDES, F.H.R.; OLIVEIRA, S.C.B.; FONSECA, F.V.; CALGAROTTO, A.K.; JOAZEIRO, P.P.; TOYAMA, M.H. Enzymatic and structural characterization of new PLA2 isoform isolated from white venom of Crotalus durissus ruruima. Toxicon, v. 53, n. 1, p.104-114, 2009.

EVANGELISTA, J.S.A.M.; MARTINS, A.M.C.; NASCIMENTO, N.R.F.; SOUSA, C.M.; ALVES, R.S.; TOYAMA, D.O.; TOYAMA, M.H.; EVANGELISTA, J.J.F.; MENEZES, D. M.; MANASSÉS, C.F.; MORAES, M.E.A.; MONTEIRO, H.A.S. Renal and vascular effects of the natriuretic peptide isolated from Crotalus durissus cascavella venom. Toxicon, v. 52, n. 7, p. 737-744, 2008.

FERRARO, G.C. , MORAES, J.R.E.; SHIMANO, A.C.; PEREIRA, G.T. ; MORAES, F.R.; BUENO DE CAMARGO, M.H. Effect of snake venom derived fbrin glue on the tendon healing in dogs. Clinical and biomechanical study. Journal of Venomous Animals and Toxins including Tropical Diseases, v. 11, n. 3, p. 261-74, 2005.

FONSECA, F.V.; ANTUNES, E.; MORGANTI, R.P.; MONTEIRO, H.S.A.; MARTINS, A.M.C.; TOYAMA, D.O.; MARANGONI, S. Characterization of a new platelet aggregating factor from crotoxin Crotalus durissus cascavella venom. The Protein Journal, v. 25, n. 3, p. 183-192, 2006.
GIORGI, R.; BERNARDI, M.; CURY, Y. Analgesic effect evoked by low molecular weight substances extracted from Crotalus durissus terrificus venom. Toxicon, v. 31, n. 1, p. 1257-1265, 1993.

GOPALAKRISHNAKONE, P.; DEMPSTER, D.W.; HAWGOOD, B.J.; ELDER, H.Y. Cellular and mitochondrial changes induced in the structure of murine skeletal muscle by crotoxin, a neurotoxic phospholipase A2 complex. Toxicon, v. 22, n. 1, p. 85-98, 1984.

GUTIERREZ, V.; KONNO, K.; CHACUR, M.; SAMPAIO, S.; PICOLO, G.; BRIGATTE, P.; ZAMBELLI, V.; CURY, Y. Crotalphine induces potent anti-nociception in neuropathic pain by acting at peripheral opioid receptors. European Journal of Pharmacology, v. 594, n. 1, p. 84-92, 2008.

HENDON, R.A.; FRAENKEL-CONRAT, H. Biological role of the two components of CrTX. Proceedings of the National Academy of Sciences, v. 68, n. 7, p. 1560-1563, 1971.

JANDROT-PERRUS, M.; LAGRUE, A. H; OKUMA, M.; BON, C. Adhesion and activation of human platelets induced by convulxin involves glycoprotein VI and integrin alpha2beta1. The Journal of Biological Chemistry, v. 272, n. 43, p. 2703527041, 1997.

KANAJI, S.; KANAJI, T.; FURIHATA, K.; KATO, K.; WARE, J.L; KUNICLI, T.J. Convulxin binds to native, human glycoprotein $\mathrm{IB} \alpha$. The Journal of Biological Chemistry, v. 278, n. 41, p. 39452-39460, 2003.

KONNO, K.; PICOLO, G.; GUTIERREZ, V.; BRIGATTE, P.; ZAMBELLI, V.; CAMARGO, C.; CURY, Y. Crotalphine, a novel potent analgesic peptide from the venom of the South American rattlesnake Crotalus durissus terrificus. Peptides, v. 29, n. 1, p. 1293-1304, 1998.

LEDUC, M.; BON, C. Cloning of subunits of convulxin, a collagen-like platelet- aggregating protein from Crotalus durissus terrificus venom. Biochemical Journal, v. 333, n. 1, p. 389-393, 1998. 
LIMA， D.; ABREU， P.; FREITAS， C.; SANTOS, D.; BORGES, R.; SANTOS, T.; CABRAL, L.; RODRIGUES, C.; CASTRO H. Snake Venom: Any Clue for Antibiotics and CAM? Evidence-based Complementary and Alternative Medicine, v. 2, n. 1, p. 39-47, 2005.

LOMONTE, B.; ANGULO, Y.; CALDERÓN, L. An overview of lysine-49 phospholipase A2 myotoxin from crotalid snake venoms and their structural determinants of myotoxic action. Toxicon, v. 42, n. 1, p. 885901, 2003.

MARTINS, A.M.C.; LIMA, A.A.M.; TOYAMA, M.H.; MARANGONI, S.; FONTELES, M. C.; MONTEIRO, H.A.S. Renal effects of supernatant from macrophages activated by Crotalus durissus cascavella venom: the role of phospholipase $\mathrm{A} 2$ and cyclooxygenase. Pharmacology \& Toxicology, v. 92, n. 1, p. 14-20, 2003.

MATSUBARA, M.H. Efeitos do veneno de Crotalus durissus terrificus, da crotoxina e de suas subunidades fosfolipase A2 e crotapotina em monocamadas de células endoteliais em cultura, 2009. 106f. Dissertação (Mestrado em Biotecnologia) - Instituto de Ciências Biomédicas, Universidade de São Paulo, São Paulo, SP, 2009.

MATSUI, T.; FUJIMURA, Y.; TITANI, K. Snake venom proteases afecting hemostasis and thrombosis. Biochim Biophys Acta, v. 1477, n.1-2, p. 146-156, 2000.

MORAES, J.R.E.; CORREA, P.H.A.; CAMPLESI, A.C.; MORAES, F.R.; Experimental use of fbrin glue derived from snake venom in non-pregnant canine uterus. Journal Venom Animals Toxins including Tropical Diseases, v.10, n.2, p.133-143, 2004.

NOGUEIRA-NETO, F.S.; AMORIM, R.L.; BRIGATTE, P.; PICOLO, G.; FERREIRA, J.R. W.A.; GUTIERREZ, V.P.; CONCEIÇÃO, I.M.; DELLA-CASA, M.S.; TAKAHIRA, R.K. B.; NICOLETTI, J.L.M.; CURY, Y. The analgesic effect of crotoxin on neuropathic pain is mediated by central muscarinic receptors and 5-lipoxygenase-derived mediators. Pharmacology, Biochemistry and Behavior, v. 91, n. 2, p. 252-260, 2008.
OLIVEIRA, D.G.; TOYAMA, M.H.; MARTINS, A.M.; HAVT, A.; NOBRE, A.C.L.; MARANGONI, S.; CÂMARA, P.R.; ANTUNES, E.; DE NUCCI, G.; BELIAM, L.O.S.; FONTELES, M.C.; MONTEIRO, H.S.A. Structural and biological characterization of a crotapotin isoform isolated from Crotalus durissus cascavella venom. Toxicon, v. 42, n. 1, p. 53-62, 2003.

PASSERO, L.F.; TOMOKANE, T.; CORBETT, C.; LAURENTI, M.D.; TOYAMA, M. Comparative studies of the anti-leishmanial activity of three Crotalus durissus sp. venoms. Parasitology Research, p.1365-1371, 2007.

PEREAÑEZ, J.Á.; NÚÑEZ, V.; HUANCAHUIRE-VEJA, S.; MARANGONI, S.; PONCE-SOTO, L.A. Biochemical and biological characterization of a PLAR (2R) from crotoxin complex of Crotalus durissus cumanensis. Toxicon, v.53, n.5, p.534-542, 2009.

PINHO, F. M. O.; PEREIRA, I. D. Ofidismo. Revista da Associação Médica Brasileira, v. 47, n. 1, p. 24-29, 2001.

POLGÁR, J.; CLEMETSON, J.M.; KEHREL, B.E.; WIEDEMANN, M.; MAGNENAT, E. M.; WELLS, T.N.; CLEMETSON, H.J. Platelet activation and signal trans by convulxin, a C-type lectin from Crotalus durissus terrificus (tropical rattlesnake) venom via the p62/GPVI collagen receptor. The Journal of Biological Chemistry, v. 272, n. 21, p. 13576-13583, 1997.

PRADO-FRANCESCHI, J. On the pharmacology of convulxin and giroxin. Memórias do Instituto Butantan, v. 52, p. 1, p. 25-26, 1990.

RANGEL-SANTOS, A.; DOS SANTOS, E.C.; LOPES-FERREIRA, M.; LIMA C.; CARDOSO, D.F.; MOTA, I.A. Comparative study of biological activities of crotoxin and CB fraction of venoms from Crotalus durissus terrificus, Crotalus durissus cascavella and Crotalus durissus collilineatus. Toxicon, v. 43, n. 7, p. 801-810, 2004. 
RAW, I.; ROCHA, M.C.; ESTEVES, M.I.; KAMIGUTI, A.S. Isolation and characterization of a thrombin-like enzyme from the venom of Crotalus durissus terrificus. Brazilian Journal of Medical and Biological Research, v. 19, n. 3, p. 333-338, 1986.

SAMPAIO, S.C.; RANGEL-SANTOS, A.C.; PERES, C.M.; CURI, Y. Inhibitory effect of phospholipase A2 isloated from Crotalus durissus terrificus venom on macrophage function. Toxicon, v. 45, n. 5, p. 671-676, 2005.

SAMY, R.P.; PACHIAPPAN, A.; GOPALAKRISHNAKONE, P.; THWIN, M.M.; HIAN, Y. E.; CHOW, L.; BOW, H.; WENG, J.T. In vitro antimicrobial activity of natural toxins and animal venoms tested against Burkholderia pseudomallei. BMC Infectious Diseases, v. 6, n. 1, p. 100-115, 2006.

SAMY, R.P.; GOPALAKRISHNAKONE, P.; THWIN, M.; CHOW, T.K.V.; BOW, H.; YAP, E.; THONG, T. Antibacterial activity of snake, scorpion and bee venoms: a comparison with purified venom phospholipase A2 enzymes. Journal of Applied Microbiology, v. 102, n. 1, p. 650-659, 2007.

SANO-MARTINS, I.S.; TOMY, S.C.; CAMPOLINA, D.; DIAS, M.B. ; DE CASTRO, S C. B.; SOUSA-E-SILVA, M.C.C.; AMARAL, C.F.S.; REZENDE, M.A.; KAMIGUTI, A. S.; WARRELL, D.A.; THEAKSTON, R.D.G. Coagulopathy following lethal and non-lethal envenoming of humans by the South American rattlesnake in Brazil. The Quarterly Journal of Medicine, v. 94, n. 10, p. 551-559, 2001.

SANTOS, E. Anfíbios e Répteis. 3.ed. Belo Horizonte: Itatiaia, 1995, 263p.

SERRANO, S.M.; MAROUN, R.C. Snake venom serine proteinases: sequence homology vs. substrate specificity, a paradox to be solved. Toxicon, v. 45 , n. 8 , p. 1115-1132, 2005.

SILVA, M.G.C. Câncer em Fortaleza: 19781980. Fortaleza, Instituto e Registro de câncer do Ceará, 1982.
SLOTTA, K.H.; FRAENKEL-CONRAT, H. Estudos químicos sobre os venenos ofídicos. Purificação e cristalização do veneno da cobra cascavel. Memórias do Instituto Butantan, v. 12, n. 1, p. 505-512, 1938.

SOARES, A.M.; MANCIN, A.; CECCHINI, A.; ARANTES, E.; FRANÇA, S.C.; GUTIÉRREZ, J.M.; GIGLIO, J. Effects of chemical modifications of crotoxin $\mathrm{B}$, the phospholipase A2 subunit of crotoxin from Crotalus durissus terrificus snake venom, on its enzymatic and pharmacological activities.

The International Journal of Biochemistry \& Cell Biology, v. 33, n. 1, p. 877-888, 2001.

TAMIETI, B.P. ; DAMATTA, R.A.; COGO, J.C.; DA SILVA, N.S. ; MITTMANN, J.P.S.C. Cytoskeleton, endoplasmic reticulum and nucleus alterations in cho-k1 cell line after Crotalus durissus terrificus (south american rattlesnake) venom treatment. Journal of Venomous Animals and Toxins Including Tropical Diseases, v.13, p. 56-58, 2007.

TOYAMA, M.H.; CARNEIRO, E.M.; MARANGONI, S.; AMARAL, M.E.C.; VELLOSO, L.A.; BOSCHERO, A.C. Isolation and characterization of a Convulxin like protein from Crotalus durisssus collilineatus venom. Journal of Protein Chemistry, v. 20, n. 7, p. 585-591, 2001.

TOYAMA, M.; OLIVEIRA, D.; BERIAM, L.; NOVELLO, J.; RODRIGUES-SIMIONI, L.; MARANGONI, S. Structural, enzymatic and biological properties of new PLA2 isoform from Crotalus durissus terrificus venom. Toxicon, v. 41, n. 1, p. 1033-1038, 2003.

TOYAMA, M.H.; TOYAMA, D.D.O; PASSERO, L.F.D.; LAURENTI, M.D.; CORBETT, C.E. ; TOMOKANE, T.Y.; FONSECA, F.V.; ANTUNES, E.; JOAZEIRO, P.P.; BERIAM, L.O.S.; MARTINS, M.A.C; MONTEIRO, H.S.A., FONTELES, M.C. Isolation of a new L-amino acid oxidase from Crotalus durissus cascavella venom. Toxicon, v. 47, n. 1, p. 47-57, 2006.

YAN, C.; LIANG, Z.; GU, Z.; YANG, Y.; REID, P.; QIN, Z. Contributions of autophagic and apoptotic mechanisms to CrTX-induced death of K562 cells. Toxicon, v. 47, n. 1, p. 521-530, 2006. 
YAN, C.; YANG, Y.; QIN, Z.; GU, Z.; REID, $\mathrm{P}$; LIANG, Z. Autophagy is involved in cytotoxic effects of crotoxin in human breast cancer cell line MCF-7 cells. Acta Pharmacologica Sinica, v. 28, n. 4, p.540548, 2007.

ZHANG, H.L.; HAN, R.; CHEN, Z.X.; CHEN, B.W.; GU, Z.L.; REID, P.F. Opiate and acetylcholine-independent analgesic actions of crotoxin isolated from Crotalus durissus terrificus venom. Toxicon, v. 48, n. 2, p. 175-182, 2006.

ZHU, Q.; WU, D.C.; ZHOU, X.P.; GONG, S.; CHENG, B.C.; QIN, Z.H. Inhibitory effect of crotoxin on the pain-evoked discharge of neurons in thalamic parafascicular nucleus in rats. Toxicon., v. 51, n. 1, p. 102-111, 2008. 